\title{
Rancang Bangun Game Android I Siap Selem Bergenre Puzzle Games
}

\author{
Ida Bagus Gde Dwipermana Sidhi, Anak Agung Ketut Agung Cahyawan Wiranatha, I \\ Made Agus Dwi Suarjaya \\ Program Studi Teknologi Informasi, Fakultas Teknik, Universitas Udayana \\ Bukit Jimbaran, Bali, Indonesia Telp. (0361) 701806 \\ e-mail: nct.noacto@gmail.com, agung.cahyawan@unud.ac.id, agussuarjaya@it.unud.ac.id
}

\begin{abstract}
Abstrak
Cerita rakyat merupakan cerita yang bersumber dari masyarakat serta tumbuh berkembang dalam masyarakat sejak masa lampau. Cerita rakyat di Bali merupakan cerita turun menurun yang memiliki nilai budaya dan pesan moral. Perkembangan teknologi yang cepat menyebabkan Cerita Rakyat Bali yang masih menggunakan media buku mulai ditinggalkan. Media baru dibuat pada penelitian ini untuk menceritakan kembali cerita rakyat dengan memanfaatkan teknologi game. Cerita Rakyat Bali yang diangkat yaitu I Siap Selem. Game I Siap Selem dikembangkan berbasis Android bergenre puzzle games. Hasil pengujian kepada 30 siswa yaitu 100\% dari kelompok siswa mengetahui isi cerita dan pesan moral dari Cerita Rakyat Bali I Siap Selem setelah memainkan game, dimana sebelumnya 80\% siswa tidak mengetahuinya. Game I Siap Selem dapat digunakan untuk melestarikan Cerita Rakyat Bali melalui game berdasarkan hasil pengujian.
\end{abstract}

Kata Kunci: Android, Cerita Rakyat Bali, I Siap Selem, Puzzle Game

\begin{abstract}
Folk stories are stories that come from the community and have grown in the community since the past. Folklore in Bali is a descending story that has cultural values and moral messages. Rapid technological developments have caused Balinese Folklore which still uses book media to be abandoned. New media was created in this study to retell folklore using game technology. The Balinese Folklore that adapted is I Siap Selem. Game I Siap Selem was developed based on the Android puzzle games. The test results to 30 students were $100 \%$ of the student group knew the contents of the story and the moral message from Balinese Folklore I Siap Selem after playing the game, where previously $80 \%$ of students did not know. Game I Siap Selem can be used to preserve Balinese Folklore through game based on the results of
\end{abstract} testing.

Keywords: Android, Balinese Folklore, I Siap Selem, Puzzle Game.

\section{Pendahuluan}

Masyarakat Bali dikenal tidak lepas dari budaya. Cerita Rakyat Bali dulunya sangat populer karena mengandung nilai budaya dan nilai moral yang disampaikan kepada para pendengarnya [1]. I Siap Selem merupakan salah satu Cerita Rakyat Bali, cerita ini memberikan pesan moral tentang bagaimana setiap kejahatan pasti mendapatkan akibatnya. Perbuatan baik selalu mendatangkan hal-hal yang baik, sedangkan perbuatan buruk selalu mendatangkan halhal yang buruk.

Cerita Rakyat Bali mulai ditinggalkan seiring dengan berkembangnya teknologi. Cerita Rakyat ditinggalkan karena para orang tua sudah mulai enggan menceritakan Cerita Rakyat kepada anak-anaknya [2]. Penelitian ini menawarkan solusi yaitu pembuatan game berbasis android dengan jenis puzzle games yang menceritakan kembali salah satu cerita rakyat Bali I Siap Selem.

Penelitian sebelumnya yang membahas tentang pelestarian budaya diantaranya adalah "Application of Basic Balinese Dance Using Augmented Reality on Android" oleh Franza [3], "Balinese Papyrus Manuscript Image Segmentation Using DBSCAN Clustering Method" oleh Wirdiani [4], "Pengenalan Tradisi Budaya Bali melalui Aplikasi Game Explore Bali Berbasis 
Android" oleh Sanjaya [5], dan "Rancang Bangun Game Tapel Bali pada Platform Android" oleh Putra [6]. Penelitian oleh Franza membahas mengenai augmented reality dari Budaya Bali yaitu Tari Bali sebagai media belajar gerakan Tari Bali yang interaktif dan menarik. Penelitian oleh Wirdiani membahas tentang pelestarian manuskrip papyrus bali yang dibaca menggunakan metode clustering menggunakan DBSCAN. Penelitian oleh Sanjaya membahas tentang game Android yang digunakan untuk mengenalkan Tradisi Budaya Bali seperti Ngerebong (Denpasar), Mekotek (Badung), Okokan (Tabanan), Makepung (Jembrana), Ngedeblag (Gianyar), Megibung, Tertekan, Gebug Ende (Karangasem) dan Ngocang, Bukakak (Buleleng) dalam bentuk permainan mengumpulkan huruf, puzzle, dan tanya jawab. Penelitian oleh Putra membahas tentang game yang merancang Topeng Bali untuk mengenalkan Budaya Bali khususnya Topeng Bali dengan menggunakan game engine CoronaSDK.

Game I Siap Selem serupa dengan penelitian sebelumnya yaitu penelitian dengan tujuan pelestarian Budaya Bali dan dikemas dalam bentuk game, cerita yang diangkat berbeda dengan penelitian sebelumnya yaitu mengenai Cerita Rakyat Bali I Siap Selem. Game I Siap Selem dibuat menggunakan aplikasi Unity dengan bahasa pemrograman C\# yang dijalankan pada platform Android. Platform Android dipilih karena dapat dimainkan di mana saja melalui smartphone dan android memiliki sensor accelerometer yang dapat digunakan untuk menggerakkan karakter. Genre Puzzle Game digunakan karena dapat melatih logika pengguna [7]. Game pada penelitian ini dirancang terdiri dari Story Mode dan Endless Mode, Story mode dibuat untuk menceritakan Cerita Rakyat Bali I Siap Selem dengan cutscene pada tiap tingkatan permainan dan Endless Mode dibuat untuk mendapatkan skor tertinggi, dimana semakin tinggi tingkat level permainan maka tingkat kesulitan meningkat.

\section{Metodologi Penelitian}

Alur penelitian diawali dengan pendefinisian masalah dan batasan masalah dari game, pengumpulan data untuk perancangan dan pembuatan game, pembuatan game menggunakan Unity, Instalasi game pada perangkat Android, pengujian terhadap game yang telah dibuat, analisis hasil pengujian game, pretest kepada siswa, demonstrasi game ke siswa, dan posttest kepada siswa, serta dilakukan analisis hasil pengukuran.

Metode yang digunakan dalam mengukur pengetahuan siswa terhadap Cerita Rakyat Bali I Siap Selem melalui Game I Siap Selem adalah Pre-Experimental dengan bentuk One Group Pretest-Postest Design. Pada metode ini terdapat pretest sebelum diberi treatment dan posttest setelah diberi treatment [8]. Treatment yang dilakukan adalah demonstrasi Game I Siap Selem. Pengujian pretest dilakukan dengan memberikan pertanyaan ke siswa tanpa demonstrasi game. Pengujian posttest dilakukan dengan memberikan pertanyaan ke siswa setelah demonstrasi game. Metode pengambilan data yang digunakan adalah kuesioner yang melibatkan siswa dalam satu kelompok. Aspek yang dinilai pada kuesioner adalah aspek cerita dan pesan moral dari Cerita Rakyat Bali I Siap Selem. Penetapan skor atau nilai yang digunakan pada kuesioner menggunakan skala Likert, yaitu Sangat Setuju (SS), Setuju (S), Tidak Setuju (TS), Sangat Tidak Setuju (STT). 


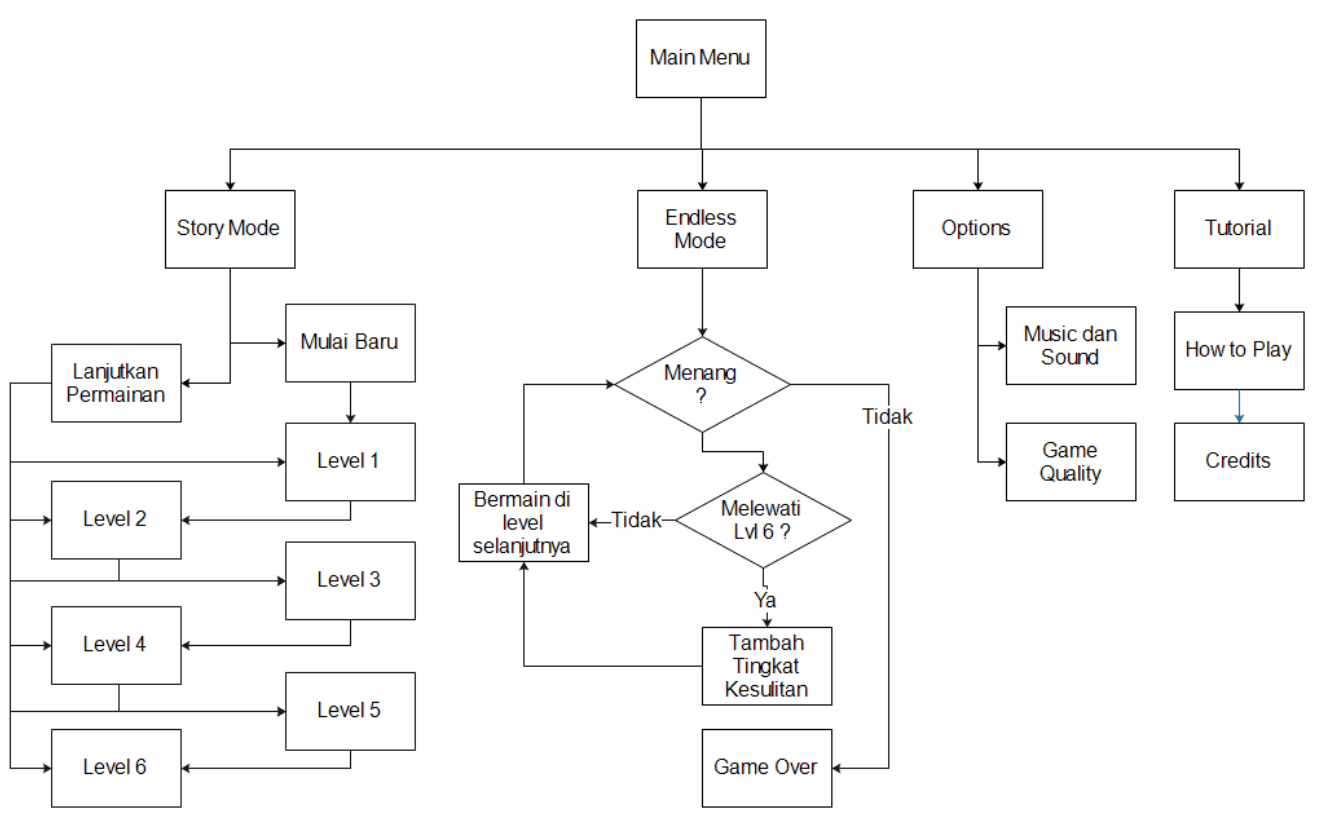

Gambar 1. Gambaran Umum Game I Siap Selem

Gambar 1 memperlihatkan gambaran secara umum tentang Game I Siap Selem. Game I Siap Selem terdiri dari empat menu yaitu, Story Mode, Endless Mode, Options, dan Tutorial. Game Story Mode dimulai dengan animasi cerita awal I Slap Selem, kemudian dilanjutkan ke level 1. Pemain menggerakkan Siap Selem yang mencari anak-anaknya. Lokasi anak siap selem ini merupakan titik tujuan pada setiap level. Pemain dihalangi rintangan untuk mencapai titik tujuan. Rintangan enemy yang berkeliling dan pintu terkunci terdapat pada setiap level. Potongan cerita I Siap Selem ditampilakan setiap level diselesaikan. Story Mode berakhir ketika melewati level 6 dan berhasil menyelesaikan mini game, kemudian ditampilkan animasi cerita akhir I Siap Selem. Selain Story Mode, terdapat Endless Mode yang merupakan tipe game yang tidak memiliki akhir, setiap 6 level tingkat kesulitan bertambah. Menu options dipilih untuk mengatur suara dan musik dalam game. Menu tutorial memperlihatkan cara untuk bermain Game I Siap Selem.

\section{Kajian Pustaka}

\subsection{Cerita Rakyat Bali I Siap Selem}

Kisah I Siap Selem secara singkat diawali dengan I Siap Selem suatu hari mengajak delapan ekor anak-anaknya ke hutan untuk mencari makanan. Saking asyiknya, tanpa terasa hari telah sore dan hujan deras, sungaipun banjir. I Siap Selem dan anak-anaknya yang mencari tempat berteduh melihat rumah Meng Kuuk. I Siap Selem meminta untuk menginap di Rumah Meng Kuuk karena desakan anak-anaknya dan Doglagan anak bungsunya belum cukup berbulu untuk menahan dingin. Siap Selem yang akan tidur mendengar Meng Kuuk berkata kepada anak-anaknya kalau mereka ingin memakan Siap Selem dan anak-anaknya. Siap Selem yang mendengar perkataan Meng Kuuk mengajak anak-anaknya untuk kabur terbang lewat jendela. Tujuh anaknya telah kabur meninggalkan Doglagan dan Siap Selem. Doglagan yang tidak punya bulu tidak bisa terbang. Siap Selem meninggalkan Doglagan sendiri bertahan hingga sayapnya kuat untuk bisa kabur dari rumah Meng Kuuk. Meng Kuuk yang melihat tinggal Doglagan tersisa berniat langsung memakan Doglagan. Doglagan meminta untuk tidak dimakan dan menunggu hingga besar agar dagingnya lebih enak. Meng Kuuk akhirnya menunggu hingga Doglagan besar.

Singkat cerita, Doglagan yang sudah besar, gemuk dan memiliki sayap berbulu. Meng Kuuk yang sudah siap memakannya meminta Dolgagan untuk mengatakan permintaan terakhirnya. Doglagan meminta untuk diajari terbang dan Meng Kuuk mengajari terbang dengan melontarkan Doglagan ke atas. Doglagan terbang tinggi sampai di atas batu. Meng Kuuk berlari ke arah Doglagan untuk memakannya. Namun, Doglagan segera terbang yang membuat Meng 
Kuuk mengigit batu. Meng Kuuk lemas, ia baru sadar bahwa dirinya diakali oleh seekor anak ayam. Meng Kuuk akhirnya pulang dengan perut lapar [9].

\subsection{Android}

Android adalah salah satu sistem operasi perangkat selular yang dirancang untuk perangkat selular layar sentuh berbasis Linux. Android merupakan sebuah platform open source sehingga banyak sekali aplikasi-aplikasi yang bisa diunduh oleh penggguna smartphone tanpa membayar biaya aplikasi. Open source memungkinkan perangkat dalam jumlah yang besar untuk menjalankan aplikasi yang sama dan menciptakan ekosistem yang jauh lebih beragam untuk para pengembang dan konsumen [10].

\subsection{Puzzle Games}

Puzzle games merupakan jenis game yang ditujukan untuk memecahkan suatu masalah atau rintangan tertentu. Game dengan jenis puzzle games membutuhkan kecepatan dan ketepatan untuk menyelesaikannya. Hampir semua tantangan merupakan masalah logika yang biasanya dibatasi oleh waktu. Puzzle game sering dimainkan untuk mengisi waktu luang saat menunggu sesuatu. Puzzle game dapat melatih otak berpikir secara taktis. Puzzle memiliki kategori yaitu, puzzle mekanik, puzzle logika, puzzle matematika, cryptic puzzle, puzzle kata dan puzzle trivia [11, 12].

\section{Hasil dan Pembahasan 4.1 Tampilan Game I Siap Selem}

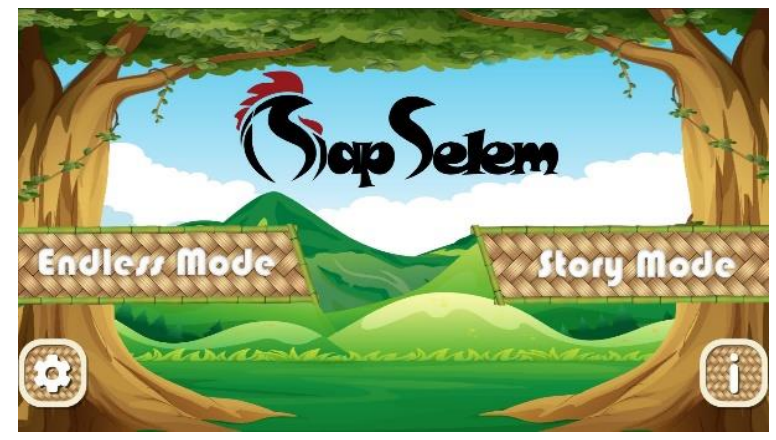

Gambar 2. Tampilan Menu Utama

Gambar 2 merupakan tampilan dari menu utama pada Game I Siap Selem. Menu Utama terdiri dari empat tombol Story Mode, Endless Mode, Pengaturan, dan Info. Tombol Endless Mode digunakan untuk mengakses tipe game Endless, dimana pemain memainkan game untuk mendapatkan nilai tertinggi. Tombol Pengaturan digunakan untuk mengakses Submenu Pengaturan. Pengaturan yang terdapat pada Game I Siap Selem adalah pengaturan suara dan kualitas game. Tombol Info digunakan untuk mengakses Submenu Info yang menampilkan informasi cara memainkan game.

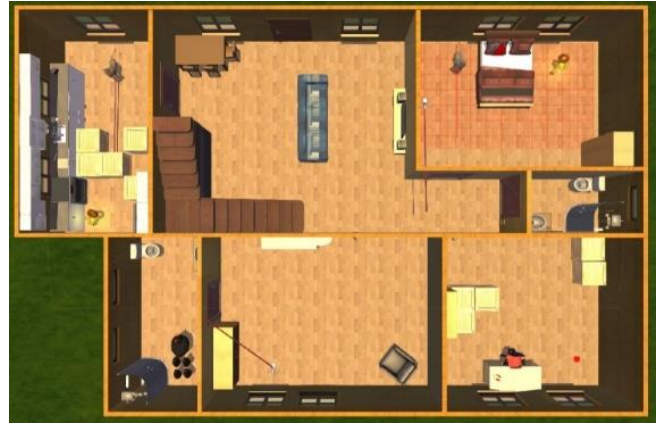

(a)

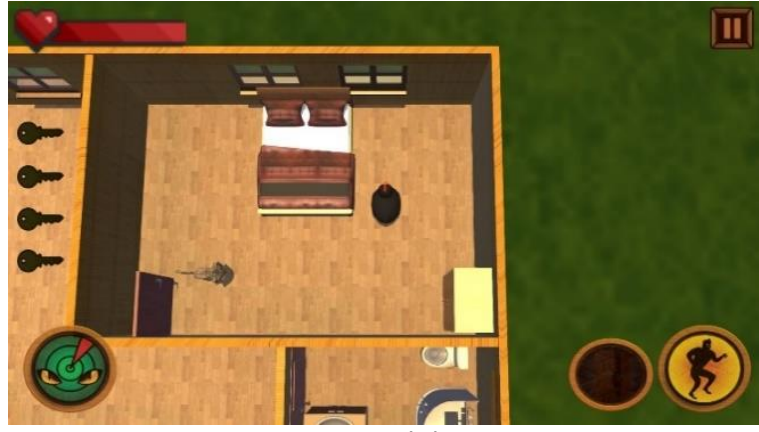

(b)

Gambar 3. Tampilan dalam Game Story Mode: (a) Keseluruhan Ruangan Game; (b) Antar Muka Game 
Gambar 3(a) memperlihatkan game Story Mode I Siap Selem yang terdapat ruangan terkunci, rintangan kotak, musuh yang berjaga dan musuh yang berjalan sesuai pola tertentu. Gambar 3(b) memperlihatkan bagaimana antar muka Story Mode yang terdapat 4 tombol dan 2 indikator permainan. Tampilan Indikator HP digunakan untuk menunjukan nyawa pemain. Indikator Kunci digunakan untuk menunjukkan kunci yang sudah dimiliki pemain. Tombol Aksi Pemain digunakan untuk melakukan aksi khusus pada karakter game. Tombol Main Menu digunakan untuk kembali ke pause menu. Pemain diminta untuk mencapai titik tujuan dimana terdapat rintangan untuk mencapati titik tujuan. Permainan berakhir jika nyawa pemain habis yang ditampilkan pada indikator HP.

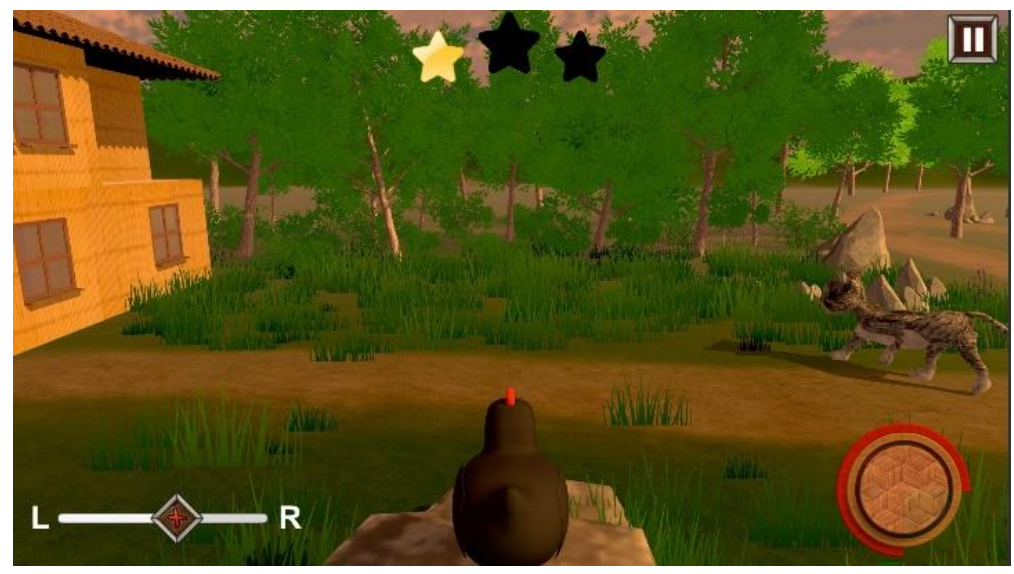

Gambar 4.Tampilan Mini Game

Gambar 4 memperlihatkan antar muka permainan Mini Game yang terdiri dari Tampilan terdiri dari indikator Score, indikator arah lompat, tombol kekuatan lompat, dan tombol main menu. Tampilan Score digunakan untuk menunjukan skor pada mini game. Tombol Arah Lompat menunjukkan arah player melompat. Tombol Power Lompat digunakan untuk melakukan lompatan sesuai dengan kekuatan yang ditunjukkan dengan warna merah. Tombol Main Menu digunakan untuk kembali ke pause menu. Pemain dapat memainkan mini game dengan meloncat melewati kucing selama 3 kali. Permainan berakhir ketika pemain berhasil meloncat 3 kali tanpa diketahui kucing.

\subsection{Hasil Pengukuran Pengetahuan Siswa Terhadap Cerita Rakyat Bali I Siap Selem melalui Game I Siap Selem}

Kelompok yang digunakan dalam penilaian adalah siswa SMA Negeri 1 Semarapura yang berjumlah 30 responden. Pretest dilakukan terlebih dahulu kepada kelompok siswa, kemudian diberikan demonstrasi Game I Siap Selem, dan terakhir dilakukan posttest kepada kelompok siswa. Hasil pretest dan posttest dibandingkan untuk melihat adanya peningkatan pengetahuan siswa terhadap cerita dan pesan moral yang terkandung dalam Cerita Rakyat Bali I Siap Selem. 


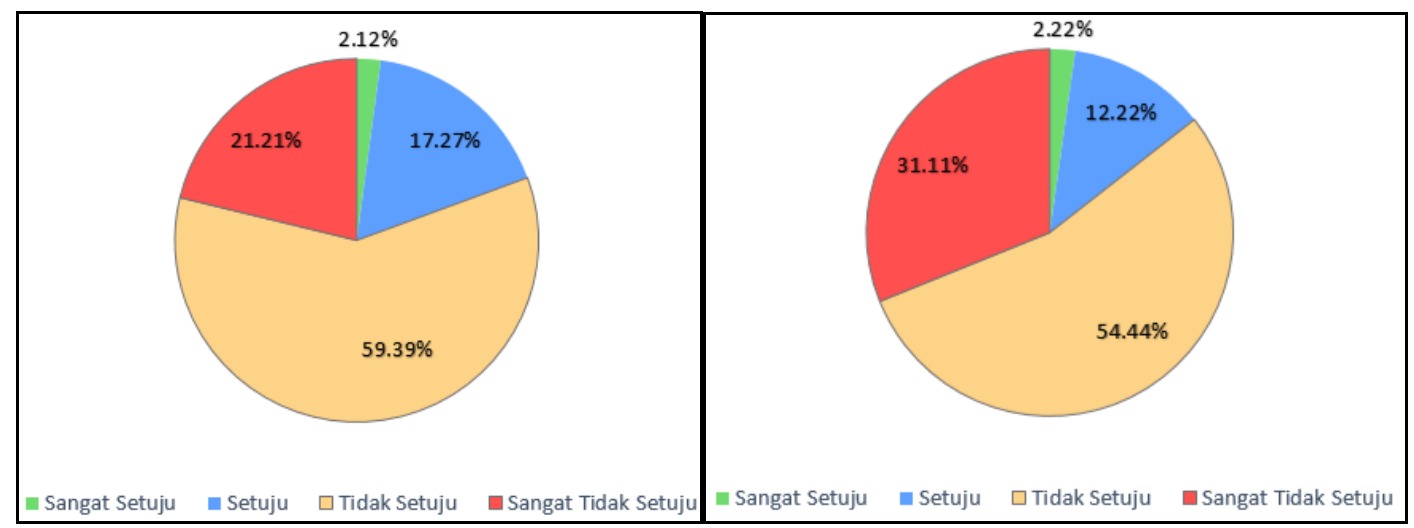

(a)

(b)

Gambar 5. Diagram Persentase Hasil Pretest: (a) Pretest Aspek Cerita; (b) Pretest Aspek Pesan Moral

Gambar 5(a) merupakan hasil pretest terhadap aspek cerita. Responden memberikan respon Sangat Tidak Setuju sebesar $21.21 \%$, Tidak Setuju sebesar 59.39\%, Setuju sebesar $17.27 \%$, dan Sangat Setuju sebesar 2.12\%. Hasil memperlihatkan bahwa $80.6 \%$ dari kelompok siswa tidak mengetahui isi cerita dari Cerita Rakyat Bali I Siap Selem dan 19.39\% dari kelompok siswa mengetahui isi cerita dari Cerita Rakyat Bali I Siap Selem.

Gambar 5(b) merupakan hasil pretest terhadap aspek pesan moral. Responden memberikan respon Sangat Tidak Setuju sebesar 31.11\%, kemudian Tidak Setuju sebesar $54.44 \%$, kemudian Setuju sebesar $12.22 \%$, dan Sangat Setuju sebesar $2.22 \%$. Hasil memperlihatkan bahwa $85.55 \%$ dari kelompok siswa tidak mengetahui pesan moral dari Cerita Rakyat Bali I Siap Selem dan $14.44 \%$ dari kelompok siswa mengetahui pesan moral dari Cerita Rakyat Bali I Siap Selem.

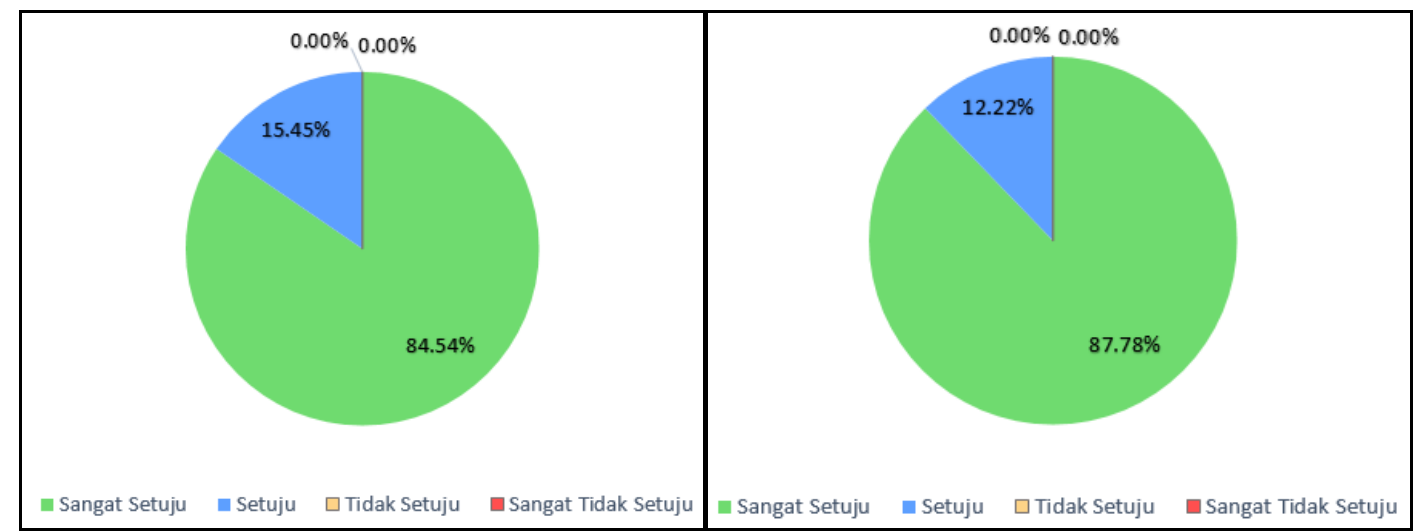

(a) (b)

Gambar 6. Diagram Persentase Hasil Posttest: (a) Posttest Aspek Cerita; (b) Posttest Aspek Pesan Moral

Gambar 6(a) merupakan hasil posttest terhadap aspek cerita. Responden memberikan respon Sangat Tidak Setuju sebesar 0\%, kemudian Tidak Setuju sebesar 0\%, kemudian Setuju sebesar $15.45 \%$, dan Sangat Setuju sebesar $84.54 \%$. Hasil memperlihatkan bahwa $0 \%$ dari kelompok siswa tidak mengetahui isi cerita dari Cerita Rakyat Bali I Siap Selem dan $100 \%$ dari kelompok siswa mengetahui isi cerita dari Cerita Rakyat Bali I Siap Selem.

Gambar 6(b) merupakan hasil posttest terhadap aspek pesan moral. Responden memberikan respon Sangat Tidak Setuju sebesar 0\%, kemudian Tidak Setuju sebesar 0\%, kemudian Setuju sebesar $12.22 \%$, dan Sangat Setuju sebesar $87.78 \%$. Hasil memperlihatkan bahwa $0 \%$ dari kelompok siswa tidak mengetahui pesan moral dari Cerita Rakyat Bali I Siap Selem dan 100\% dari kelompok siswa mengetahui pesan moral dari Cerita Rakyat Bali I Siap Selem. 
Perbandingan antara hasil pretest dan hasil posttest yang telah dilakukan, dipaparkan melalui Tabel 1.

Tabel 1. Perbandingan Hasil Pretest dan Posttest

\begin{tabular}{ccccc}
\hline No & Variable Penilaian & Kriteria & Hasil Pretest & Hasil Posttest \\
\hline 1 & Aspek Cerita & Sangat Setuju & $2.12 \%$ & $84.54 \%$ \\
& & Setuju & $17.27 \%$ & $15.45 \%$ \\
& & Tidak Setuju & $59.39 \%$ & $0 \%$ \\
& & Sangat Tidak Setuju & $21.21 \%$ & $0 \%$ \\
2 & Aspek Pesan Moral & Sangat Setuju & $2.22 \%$ & $87.78 \%$ \\
& & Setuju & $12.22 \%$ & $12.22 \%$ \\
& & Tidak Setuju & $54.44 \%$ & $0 \%$ \\
& & Sangat Tidak Setuju & $31.11 \%$ & $0 \%$ \\
\hline
\end{tabular}

Tabel 1 memperlihatkan bahwa pada aspek cerita, kriteria Sangat Setuju bernilai $2.12 \%$ dan Setuju bernilai $17.27 \%$ pada pretest, kemudian berubah menjadi $84.54 \%$ Sangat Setuju dan $15.45 \%$ Setuju pada postest. Kriteria Tidak Setuju bernilai $59.39 \%$ dan Sangat Tidak Setuju bernilai $21.21 \%$ pada pretest, kemudian berubah menjadi $0 \%$ Tidak Setuju dan 0\% Sangat Tidak Setuju. Hasil membuktikan bahwa sebelum siswa memainkan Game I Siap Selem, hampir $80.6 \%$ dari kelompok siswa tidak mengetahui isi cerita dari Cerita Rakyat Bali I Siap Selem, kemudian setelah memainkan Game I Siap Selem, 100\% dari kelompok siswa mengetahui isi cerita dari Cerita Rakyat Bali I Siap Selem.

Beralih pada aspek pesan moral, kriteria Sangat Setuju bernilai $2.22 \%$ dan Setuju bernilai $12.22 \%$ pada pretest, kemudian berubah menjadi $87.78 \%$ Sangat Setuju dan $12.22 \%$ Setuju pada postest. Kriteria Tidak Setuju bernilai $54.44 \%$ dan Sangat Tidak Setuju bernilai $31.11 \%$ pada pretest, kemudian berubah menjadi 0\% Tidak Setuju dan 0\% Sangat Tidak Setuju. Hasil membuktikan bahwa sebelum siswa memainkan Game I Siap Selem, hampir 85.55\% dari kelompok siswa tidak mengetahui pesan moral yang terkandung dalam Cerita Rakyat Bali I Siap Selem, kemudian setelah memainkan Game I Siap Selem, 100\% dari kelompok siswa mengetahui pesan moral yang terkandung dalam Cerita Rakyat Bali I Siap Selem.

\section{Kesimpulan}

Game I Siap Selem yang dihasilkan dari penelitian ini merupakan game dengan genre Puzzle Games, yaitu pemain melewati rintangan untuk mencapai titik tujuan sebagai akhir level. Game I Siap Selem menceritakan kembali Cerita Rakyat I Siap Selem yang pemainnya memerankan tokoh I Siap Selem dan Doglagan. Game I Siap Selem bertujuan untuk melestarikan Budaya Bali khususnya pada Cerita Rakyat Bali yang memiliki pesan moral yang dapat meningkatkan aspek budi pekerti pada kalangan pemain game. Hasil uji coba yang diperoleh adalah semula $80.6 \%$ siswa tidak mengetahui isi cerita dan $85.55 \%$ siswa tidak mengetahui pesan moral dari cerita I Siap Selem sebelum memainkan game dan berubah menjadi $100 \%$ siswa mengetahuinya setelah memainkan game. Siswa dapat mengetahui pesan moral dari cerita karena pada game terdapat potongan cerita yang ditampilkan menggunakan animasi. Berdasarkan hasil uji coba yang didapat, Game I Siap Selem dapat digunakan sebagai salah satu media untuk melestarikan Cerita Rakyat Bali.

\section{Daftar Pustaka}

[1] L. Sebo, Andayani, and S. Subiyantoro, "Nilai Pendidikan Karakter dan Kearifan Lokal Legenda Wae Reke Masyarakat Ngada, Nusa Tenggara Timur dalam Relevansinya dengan Pembelajaran Sastra Tingkat SLTP/ Character Values and Local Wisdom in the Legend of Wae Reke of the Ngada People of Eastern Nusa Tenggara and their Relevance in the Study of Literature at the Junior Secondary Level", Aksara, vol. 2, 2017. 
[2] I. F. Sari, A. C. Tamsin, and Hamidin, "Kategori dan Fungsi Sosial Cerita Rakyat Di Nagari Guguak Sarai", Jurnal Pendidikan Bahasa dan Sastra Indonesia, vol. 1, 2012.

[3] N. P. S. Franza, A. A. K. O. Sudana, and K. S. Wibawa, "Application of Basic Balinese Dance Using Augmented Reality on Android", Journal of Theoretical and Applied Information Technology, vol. 90, pp. 61-66, 2016.

[4] A. Wirdiani, S. Sukma, O. Sudana, and S. Wibawa, "Balinese Papyrus Manuscript Image Segmentation Using DBSCAN Clustering Method", Journal of Theoretical \& Applied Information Technology, vol. 96, 2018.

[5] D. P. A. Sanjaya, I. K. A. Purnawan, and N. K. D. Rusjayanthi, "Pengenalan Tradisi Budaya Bali melalui Aplikasi Game Explore Bali Berbasis Android", Lontar Komputer, vol. 7, 2016.

[6] I. D. M. Y. A. Putra, A. A. K. A. C. Wiranatha, and P. W. Buana, "Rancang Bangun Game Tapel Bali pada Platform Android", Lontar Komputer, vol. 6, 2015.

[7] M. R. Johnson, "Casual Games Before Casual Games: Historicizing Paper Puzzle Games in an Era of Digital Play", Games and Culture Journal of Sage Publications, 2018.

[8] M. S. Mustaqbal, R. F. Firdaus, and H. Rahmadi, "Pengujian Aplikasi Menggunakan Black Box Testing Boundary Value Analysis", Jurnal IImiah Teknologi Informasi Terapan, vol. 1, 2015.

[9] K. Keriana, Pupulan Satua Bali. Gianyar: Gianyar Grafika, 2006.

[10] M. G. Arsawiguna, A. A. K. A. C. Wiranatha, and K. S. Wibawa, "Rancang Bangun Aplikasi Game Tajen Berbasis Android menggunakan Artificial Intelligence," Lontar Komputer, vol. 6, 2015.

[11]A. N. Putri, "Optimasi Alghoritma Breadth First Search pada Game Engine 3D Third Person Shooter Maze Berbasis Agen Cerdas Android", Jurnal Transformatika, vol. 14, 2016.

[12] S. G. A. Bhaskara, P. W. Buana, and I. K. A. Purnawan, 'Permainan Edukasi Labirin Virtual Reality Dengan Metode Collision Detection Dan Stereoscopic', Lontar Komputer, vol. 8, 2017. 